\title{
COMPOSITION AND \\ FUNCTION OF \\ CELL MEMBRANES
}

Application to the Pathophysiology

of Muscle Diseases 


\section{ADVANCES IN EXPERIMENTAL MEDICINE AND BIOLOGY}

Editorial Board:

NATHAN BACK, State University of New York at Buffalo

NICHOLAS R. DI LUZIO, Tulane University School of Medicine

EPHRAIM KATCHALSKI-KATZIR, The Weizmann Institute of Science

DAVID KRITCHEVSKY, Wistar Institute

ABEL LAJTHA, Rockland Research Institute

RODOLFO PAOLETTI, University of Milan

Recent Volumes in this Series

Volume 134

HAMSTER IMMUNE RESPONSES IN INFECTIOUS AND ONCOLOGIC DISEASES

Edited by J. Wayne Streilein, David A. Hart, Joan Stein-Streilein, William R. Duncan, and Rupert E. Billingham

Volume 135

DIET AND RESISTANCE TO DISEASE

Edited by Marshall Phillips and Albert Baetz

Volume 136

BIOLOGICAL REACTIVE INTERMEDIATES II: Chemical Mechanisms and Biological Effects

Edited by Robert Snyder, Dennis V. Parke, James J. Kocsis,

David J. Jollow, G. Gordon Gibson, and Charlotte M. Wintmer

Volume 137

THE RUMINANT IMMUNE SYSTEM

Edited by John E. Butler

Volume 138

HORMONES AND CANCER

Edited by Wendell W. Leavitt

Volume 139

TAURINE IN NUTRITION AND NEUROLOGY

Edited by Ryan Huxtable and Herminia Pasantes-Morales

Volume 140

COMPOSITION AND FUNCTION OF CELL MEMBRANES: Application to the Pathophysiology of Muscle Diseases

Edited by Stewart Wolf and Allen K. Murray

Volume 141

BIOCHEMISTRY AND FUNCTION OF PHAGOCYTES

Edited by F. Rossi and P. Patriarca

Volume 142

BIOCHEMISTRY AND BIOLOGY OF CORONAVIRUSES

Edited by V. ter Meulen, S. Siddell, and H. Wege

Volume 143

RELAXIN

Edited by Ralph R. Anderson 


\section{COMPOSITION AND FUNCTION OF CELL MEMBRANES Application to the Pathophysiology of Muscle Diseases}

Edited by

Stewart Wolf

St. Luke's Hospital

Bethlehem, Pennsylvania

Professor of Medicine, Temple University

Philadelphia, Pennsylvania

Chairman, Scientific Advisory Committee

Muscular Dystrophy Association

and

Allen K. Murray

Assistant to the Director of Research Development

Muscular Dystrophy Association

New York, New York 


\section{Library of Congress Cataloging in Publication Data}

Totts Gap Colloquium on the Relation of Cell Membranes to Membrane-bound Enzymes (1980 : Totts Gap Institute) Composition and function of cell membranes.

(Advances in experimental medicine and biology ; v. 140)

"Edited transcript of the Totts Gap Colloquium on the Relation of Cell Membranes to Membrane-bound Enzymes held May 19-21, 1980 and sponsored by the Muscular Dystrophy Association"-T.p. verso.

Bibliography: $p$.

Includes index.

1. Muscles - Diseases - Congresses. 2. Plasma membranes-Congresses. 3. Muscular dystrophy-Congresses. I. Wolf, Stewart George, 1914- . II. Murray, Allen K. III. Muscular Dystrophy Association. IV. Title. V. Series. [DNLM: 1. Cell membraneCongresses. 2. Muscular dystrophy-Etiology-Congresses. W1 AD559 v. 140 / WE 559 T721c 1980]

$\begin{array}{llrl}\text { RC925.6.T67 } 1980 & 611^{\prime} .0186 & 81-17892\end{array}$ $\begin{array}{ll}\text { ISBN 0-306-40883-X } & \text { AACR2 }\end{array}$

An edited transcript of the Totts Gap Colloquium on the Relation of Cell Membranes to Membrane-Bound Enzymes held May 19-21, 1980 and sponsored by the Muscular Dystrophy Association

ISBN-13: 978-1-4684-4114-7

e-ISBN-13: 978-1-4684-4112-3

DOI: $10.1007 / 978-1-4684-4112-3$

(C) 1981 Plenum Press, New York

Softcover reprint of the hardcover 1st edition 1981

A Division of Plenum Publishing Corporation

233 Spring Street, New York, N.Y. 10013

All rights reserved

No part of this book may be reproduced, stored in a retrieval system, or transmitted in any form or by any means, electronic, mechanical, photocopying, microfilming, recording, or otherwise, without written permission from the Publisher 
TOTTS GAP MEDICAL RESEARCH LABORATORIES, INC.

\section{OFFICERS, DIRECTORS, AND TRUSTEES}

Mark D. Altschule, M.D., President; Visiting Professor, Harvard Medical School; Consultant, Francis A. Countway Library of Medicine, Boston, Massachusetts

Beatrice B. Berle, M.D., Vice President; Former Assistant Clinical Professor of Medicine and Preventive Medicine, Cornell University Medical College, and Associate Professor of Clinical Medicine, New York University School of Medicine, New York, New York; Former Research Associate, Albert Einstein College of Medicine, New York

Stewart Wolf, M.D., Secretary; Vice President for Medical Affairs, St. Luke's Hospital, Bethlehem, Pennsylvania; Professor of Medicine, Temple University School of Medicine, Philadelphia, Pennsylvania

Phylls B. Sheridan, Ed.D., Treasurer; Assistant to the Vice President for Medical Affairs, St. Luke's Hospital, Bethlehem, Pennsylvania; Former Administrator, Bureau of Applied Social Research, Columbia University, New York

William B. Bean, M.D., Sir William Osler Professor of Medicine, University of lowa, lowa City, lowa; Former Director, Institute for the Humanities in Medicine, University of Texas Medical Branch, Galveston, Texas

Andre Cournand, M.D., Professor Emeritus of Medicine, Special Lecturer, College of Physicians and Surgeons of Columbia University, New York

Mr. George Giaquinto, President, Atlantic Apparel, Wind Gap, Pennsylvania; Former Mayor, Roseto, Pennsylvania

Miss Helen Goodell, Research Associate Emeritus, Department of Neurology, Research Consultant Emeritus, Westchester Division, Cornell-New York Hospital Medical Center, New York and White Plains

Mr. Albert Rosenfeld, Consultant on Future Programs, The National Foundation, New York; Former Science Editor, Saturday Review

Sol Sherry, M.D., Professor and Chairman, Department of Medicine, Temple University School of Medicine, Philadelphia, Pennsylvania

Eliot Stellar, Ph.D., Professor of Psychology and former Provost, University of Pennsylvania, Philadelphia, Pennsylvania

Mr. Richard Suck, Former President, St. Luke's Hospital, Bethlehem, Pennsylvania

Mr. Oscar Swarth, President, D'San Corporation, New York

Nicholas T. Werthessen, Ph.D., Bioscientist, Office of Naval Research; Senior Research Associate, Brown University, Providence, Rhode Island

Joseph M. White, M.D., Executive Director for Medical Education, St. Paul's Hospital; Professor of Anesthesiology, University of Texas Southwestern Medical School, Dallas, Texas 


\section{PREFACE}

The present volume contains the edited transcript of a Totts Gap Colloquium held May 19-21, 1980 sponsored by the Muscular Dystrophy Association. The aim of the colloquium was to bring into focus data relating to cell membranes that might contribute to understanding the pathogenic mechanism of Duchenne muscular dystrophy.

A major impediment to progress in understanding the pathogenesis of muscular dystrophy has been the failure, so far, to identify the basic genetic defect. Pending the identification of the genetic lesion in Duchenne dystrophy and, in view of scattered but persistent indications of a basic membrane disturbance, it seemed worthwhile to explore in open dialogue the current state of knowledge of membrane morphology and chemistry with an eye to possible leads for further investigation.

The participants, drawn from a variety of interested disciplines, attempted to synthesize and reconcile their findings and to identify crucial areas of ignorance in need of exploration. For the most part they avoided specialized jargon and spoke in a language that could be understood by the rest of the group. Apart from providing a review of widely varying approaches to the study of the composition and behavior of cell membranes, the discussions brought together current thinking on strategies and approaches to the study of the pathogenesis of muscular dystrophy. Already the personal contacts made at the colloquium have led to new inter-institutional collaborative investigations.

The discussions were recorded, transcribed, edited and to some extent, rearranged to fit into a sequence of chapters. Valuable assistance was provided by Helen Goodell who helped with the editing and Joy Colarusso Lowe whose patience and expertise made possible the manuscript itself. 


\section{PARTICIPANTS}

Gunter Blobel, M.D., Ph.D., Department of Cell Biology, Rockefeller University, New York

Daniel Branton, Ph.D., Biological Laboratories, Harvard University: Boston, Massachusetts

D. Allen Butterfield, Ph.D., Department of Chemistry, University of Kentucky, Lexington, Kentucky

John S. Charnock, Ph.D., Assistant Chief, CSIRO, Division of Human Nutrition, Glenthorne Laboratories, Adelaide, South Australia

Peter R. Cullis, Ph.D., Department of Biochemistry, University of British Columbia, Vancouver, British Columbia

Benjamin de Kruijff, Ph.D., Department of Biochemistry, University of Utrecht, The Netherlands

Andrew G. Engle, M.D., Department of Neurology, Mayo Clinic, Rochester, Minnesota

Sidney Fleischer, Ph.D., Department of Molecular Biology, Vanderbilt University, Nashville, Tennessee

Luis Glaser, Ph.D., Department of Biological Chemistry, Washington University School of Medicine, St. Louis, Missouri

Michael Glaser, Ph.D., Department of Chemistry, University of Illinois, Urbana, Illinois

Jose Gonzales-Ros, Ph.D., Department of Biochemistry, Virginia Commonwealth University, Richmond, Virginia

John L. Howland, Ph.D., Department of Biology, Bowdoin College, Brunswick, Maine

James S. Hyde, Ph.D., Department of Radiology, National Biomedical ESR Center, Medical College of Wisconsin, Milwaukee, Wisconsin 
Claudia Kent, Ph.D., Department of Biochemistry, Purdue University, W. Lafayette, Indiana

Melvin L. Moss, Ph.D., Director of Research Development, Muscular Dystrophy Association, New York

Allen K. Murray, Ph.D., Assistant to the Director of Research Development, Muscular Dystrophy Association, New York

Jane H. Park, Ph.D., Department of Physiology, Vanderbilt University, Nashville, Tennessee

Alexander Sandra, Ph.D., Department of Anatomy, University of Iowa, Iowa City, Iowa

Donald L. Schotland, M.D., Department of Neurology, Hospital of the University of Pennsylvania, Philadelphia, Pennsylvania

Warren Strittmatter, M.D., Department of Neurology, Baylor College of Medicine, Houston, Texas

Richard Strohman, Ph.D., Health and Medical Sclence Program, University of California, Berkeley, California

Joseph Willner, Ph.D., Department of Neurology, Columbia University College of Physicians and Surgeons, New York

Stewart Wolf, M.D., St. Luke's Hospital, Bethlehem, Pennsylvania, Temple University School of Medicine, Philadelphia, Pennsylvania and Totts Gap Institute, Bangor, Pennsylvania 
CONTENTS

CHAPTER 1

PHYLOGENY, STRUCTURE AND COMPOSITION OF

CELL MEMBRANES $\ldots \ldots \ldots \ldots \ldots \ldots \ldots \ldots \ldots \ldots \ldots \ldots \ldots \ldots \ldots$

CHAPTER 2

CHARACTERISTICS AND BEHAVIOR OF PLASMA MEMBRANES .... 55

CHAPTER 3

REGULATION OF MEMBRANE FUNCTIONS .............. 107

CHAPTER 4

THE LIPID BILAYER, MECHANISMS OF FUSION AND

TRANSMEMBRANE TRANSPORT $\ldots \ldots \ldots \ldots \ldots \ldots \ldots \ldots \ldots \ldots \ldots$

CHAPTER 5

MEMBRANE ALTERATIONS IN ERYTHROCYTE AND CULTURED

FIBROBLASTS IN NEUROMUSCULAR DISEASES $\ldots \ldots \ldots \ldots \ldots \ldots 187$

CHAPTER 6

ABNORMALITIES IN MUSCLE IN DUCHENNE MUSCULAR

DYSTROPHY. Synthesis and Speculation ........... 211

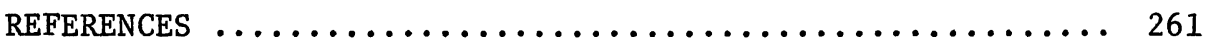

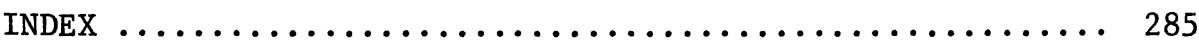

